\title{
Evaluation of Anti-Hyperglycaemic activity of Ethanolic Extract of Stems of Bryophyllum pinnatum against Type 2 Diabetic rats
}

\author{
Research Article
}

\section{Vijay $\mathbf{A}^{1}$, Kathiresan $\mathrm{K}^{2}$, Pandian $\mathbf{P}^{2}$ *}

1. PG Scholar, 2. Associate Professor, Department of Pharmacy, Annamalai University, Annamalainagar, Chidambaram.

\begin{abstract}
To evaluate antidiabetic activity of stems of Bryophyllum pinnatum in Alloxan male Wistar rats cause diabetes. Thirty albino rats were divided into distinct five groups $(n=6)$. By Intraperitoneal injection caused the onset of diabetes of Alloxan $(120 \mathrm{mg} / \mathrm{Kg})$. vehicle control, negative control, 200 , and $400 \mathrm{mg} / \mathrm{kg}$ ethanolic extracts were given orally in 28 days as single administrations to the vehicle control, diabetic control, normal group, and test groups. Glucose, (fasting and post prandial for $1^{\text {st }}$ and $21^{\text {st }}$ day) serum cholesterol, Triglyceride, HDL (High density lipoprotein), LDL (Low density lipoprotein) Serum creatinine and urea were estimated with blood tests. The student's $\mathrm{t}$ test was performed to evaluate the results. In diabetic rats, a low dose of ethanol extract $200 \mathrm{mg} / \mathrm{kg}$ significantly decreased all biochemical markers of diabetes. A $400 \mathrm{mg} / \mathrm{kg}$ of ethanol extract was given to diabetic rats and showed substantial decreases in blood glucose and biochemical parameters. Both ethanol high and low dose extracts show antidiabetic activity in Alloxan induced diabetes.
\end{abstract}

Key Words: Antidiabetic, Wistar rats, Ethanol, Glucose, Biochemical markers.

\section{Introduction}

Diabetes is a metabolic disorder disease of sugars, fats and proteins. Typically affecting a wide demographic, it is the largest problem throughout the world. Diabetes is not a specific condition, but rather a metabolic disorder that occurs with a variety of causes, including insulin resistance. The main symptoms of diabetes mellitus are increased appetite, increased urinary production, ketonemia and ketonuria, which occur due to defects in the metabolism of carbohydrates, fats, and proteins. It is called ketoacidosis when ketones are found in the blood or urine, so medication should be begun as soon as possible, if not, it might exacerbate the condition. Diabetes mellitus has resulted in microvascular (retinopathy, neuropathy and nephropathy) and macrovascular (heart attack, stroke and peripheral artery disease) complications. $(1,2)$ The rapid increase in unhealthy habits, urbanisation and ageing is largely due to diabetes. Reactive oxygen species (ROS) that causes lipid peroxidation and membrane damage are caused by hypoglycemia which is a consequence of diabetes mellitus. ROS plays a significant role in the development of nerve disease, kidney disease and cataracts in diabetes. Antioxidants shield $\beta$-cells from

\section{* Corresponding Author:}

\section{Pandian P}

Associate Professor,

Department of Pharmacy,

Annamalai University,

Annamalainagar, Chidambaram-608002. India.

Email Id: pandian0071@,rediffmail.com oxidation and thus play a significant role in diabetes prevention. Plants which are rich in antioxidants including tannins, flavonoids, vitamin $\mathrm{C}$ and $\mathrm{E}$ will maintain the role of $\beta$-cells and prevent the development of ROS caused by diabetes. Polyphenols, which are classified into many different groups, such as flavonoids, tannins and stilbenes, are considered to have numerous health-promoting effects, including antioxidant, anti-inflammatory, antidiabetic and antienzyme activity. As a main enzyme, aldose reductase catalyses Glucose to sorbitol is derived from glucose and the molecule is linked to diabetes complications such as peripheral neuropathy and retinopathy. Studies have demonstrated the efficacy of aldose reductase inhibitors and alpha-glucosidase inhibitors in treating diabetic complications. (3) The study aims to include accessible data on diabetes mellitus, its epidemiology, causes of diabetes, pathophysiology, available cures, diagnostic criteria, primary screening model available, herbal approach to being treated for diabetes with medicinal plants.

\section{Materials and Methods \\ Plant Details}

Even though this is not the focus of this paper, the plant Bryophyllum pinnatum is a species of semiprostrate tropical plant that fills the rain forest of Guatemala and Mexico. The hematolly plant is a perennial plant that grows in the wild and is used as a common medicinal plant in tropical Africa, China, Australia, and Ayurvet. It has been used in Asia as a Traditional Medicine as far back as the 5,000 B.C. It is now being used in countries all over the world for cures of different illnesses. The leaf extracts of this plant have been used as a cure for illnesses including infectious, 
Vijay A et.al., Evaluation of Anti-Hyperglycaemic activity of Bryophyllum pinnatum against Type 2 Diabetic rats

fungal and viral diseases. The herb Bryophyllum pinnatum, or the tiny "love plant" plant, aids anxiety by raising high in the day, and bringing itself down low in the night. It is referred to by many names, such as Ephedra, and is known to grow in many locations in nature, including in many different types of plants. Also, not to be forgotten, like Ayurveda medicine, and other ways of medicine around the world, there has been a long history of using ephedrine in medicine. The different medicinal ingredients in this plant are used to cure multiple diseases, ranging from bacterial infections to viral infections in both humans and animals. (4-5)

\section{Collection of plant materials}

The fresh stem of the plant Bryophyllum Pinnatum was collected from Kachrapalayam Hills, Kallakurichi District, Tamil Nadu, India. The collected plant material was washed with tap water for 3 times and sterilized by spraying with $70 \%$ alcohol. The sterilized plant material was shade dried at room temperature to avoid chemical changes and frequently observed for any fungal contamination as the plant material rich in water content. When the plant material was completely dried, it is subjected to prepare fine powder with the help of pestle and motor. The fine powder is collected and used for extraction of crude drug in ethanol solvents by Soxhlet extraction method. (6)

\section{Extraction of the plant material}

$300 \mathrm{~g}$ of finely powdered stems powder was defatted with $2 \mathrm{~L}$ ether in a soxhlet apparatus for $48 \mathrm{~h}$. After extraction the extracts were separately concentrated by distillation and dried at room temperature until solid mass is formed. The collected extracts were weighed and stored at room temperature for further verification. The percentage yield was calculated by using following formula

Yield $(\%)=(\mathrm{W} 1 * 100) / \mathrm{W} 2$

Where, $\mathrm{W} 1=$ weight of the extract residue obtained after solvent removal;

$\mathrm{W} 2=$ weight of the plant powder

\section{Experimental animals}

Male Wistar rats of 6-8 weeks of age, weighing between 150-250 $\mathrm{g}$ was obtained from Animal House department of pharmacy, Annamalai University. The rats are kept in normal conditions of temperature and humidity $\left(25^{\circ} \mathrm{C} \pm 50^{\circ} \mathrm{C}\right)$, relative humidity $(55 \pm 10 \%)$, and $12 / 12 \mathrm{~h} \mathrm{light/dark}$ cycle. Animals were fed commercial pellets and water, although it was not known how much was fed. The research protocols were approved by the Institutional Animal Care Committee (IAEC), and were in compliance with the Committee for the Purpose of Control and Supervision of Experiments on Animals (CPCSEA) guidelines (Approval No: AU-IAEC/1265/11/19/M.Pharm/ 11/2019-20).

\section{Experimental induction of diabetes}

The animals were partitioned into five groups of six each. Grouping of animals was listed in Table 1.
The animals will be They studied overnight fasting and confirmed the initial blood glucose of a rat tail at the end of it. Alloxan was dissolved in regular saline and then diluted with citrate buffer. Insulin-deficient diabetes was induced in overnight fasted rats with a single intraperitoneal injection dose of $120 \mathrm{mg} / \mathrm{kg}$ alloxan. It was found with blood glucose levels at $72 \mathrm{~h}$. The animals were studied with blood glucose concentrations exceeding $250 \mathrm{mg} / \mathrm{dl}$. (7)

The vehicle (saline), Metformin and extracts was administered to the appropriate animals and followed for 28 days. Metformin and the extracts were freshly distributed in standard saline and sterile water before it was administered. The fasting body weight, blood glucose level, was calculated 1st and 21st day, from the rat tail vein.

\begin{tabular}{|c|c|c|c|}
\hline Groups & $\begin{array}{c}\text { No. of } \\
\text { animals }\end{array}$ & $\begin{array}{c}\text { Group } \\
\text { specification }\end{array}$ & Treatment \\
\hline Group I & 6 & $\begin{array}{l}\text { Vehicle } \\
\text { control }\end{array}$ & $\begin{array}{l}\text { Administered with } \\
\text { portable water for } 28 \\
\text { days }\end{array}$ \\
\hline $\begin{array}{l}\text { Group } \\
\text { II }\end{array}$ & 6 & $\begin{array}{c}\text { Negative } \\
\text { control }\end{array}$ & $\begin{array}{l}\text { Receives alloxan } 120 \\
\mathrm{mg} / \mathrm{kg} / \text { P.o. (i.p) at the } \\
\text { day of induction }\end{array}$ \\
\hline $\begin{array}{l}\text { Group } \\
\text { III }\end{array}$ & 6 & $\begin{array}{c}\text { Test } 2 \\
\text { (Extract) }\end{array}$ & $\begin{array}{l}\text { Diabetic rats to } \\
\text { treated with } \\
\text { B.pinnatum high dose } \\
400 \mathrm{mg} / \mathrm{kg}, \text { p.o for } 28 \\
\text { days }\end{array}$ \\
\hline $\begin{array}{l}\text { Group } \\
\text { IV }\end{array}$ & 6 & $\begin{array}{c}\text { Test1 } \\
\text { (Extract) }\end{array}$ & $\begin{array}{l}\text { Diabetic rats to } \\
\text { treated with } B \text {. } \\
\text { pinnatum low dose } \\
200 \mathrm{mg} / \mathrm{kg} \text {, } \\
\text { metformin low dose } \\
150 \mathrm{mg}, \text { p.o for } 28 \\
\text { days }\end{array}$ \\
\hline $\begin{array}{l}\text { Group } \\
\text { V }\end{array}$ & 6 & Standard & $\begin{array}{l}\text { Diabetic rats were } \\
\text { treated with } \\
\text { metformin for } 28 \\
\text { days }(150 \mathrm{mg} / \mathrm{kg})\end{array}$ \\
\hline
\end{tabular}

\section{Body weight analysis}

The body weights of the experimental animals are assessed on the first and 21st day of the required treatment showed in Table- 2 .

Table 2: Body weight (gms) at different time intervals

\begin{tabular}{|c|c|c|c|}
\hline \multirow{2}{*}{ Groups } & \multirow{2}{*}{ Treatment } & Body weight & \\
\hline & & $1^{\text {st }}$ day & $21^{\text {st }}$ day \\
\hline Group & ntrol & 108.1 & $\begin{array}{l}115.8 \\
\pm 2.04\end{array}$ \\
\hline Grou & Negative & 4 & $\begin{array}{c}142.8 \pm \\
3.74\end{array}$ \\
\hline Gro & & $158.0 \pm 2.08$ & $\begin{array}{c}138.0 \pm \\
1.22\end{array}$ \\
\hline Group IV & $\begin{array}{l}\text { Low dose of } \\
\text { ethanol extract }\end{array}$ & $172.5 \pm 1.91$ & $\begin{array}{c}151.0 \pm \\
3.32\end{array}$ \\
\hline Group & Standard & $189.9 \pm 2.96$ & $\begin{array}{c}166.2 \pm \\
1.25\end{array}$ \\
\hline
\end{tabular}






\section{Study protocol}

All 5 groups of rats on 1st day and 21st days blood was collected. The parameter like blood glucose level for fasting and post prandial, biochemical parameters are observed and tabulated.

\section{Statistical analysis}

The findings were expressed with the mean \pm SEM. Student's t-test was used to analyse the outcomes of all classes of animals.

\section{Sample collection}

In this study, all the groups were treated with respective extracts and standard drugs. After the administration of the procedure, the animals were anaesthetized by ketamine hydrochloride and blood was obtained from retro-orbital sinus. The serum was allowed to clot at room temperature and then was centrifuged at 10000 rpm for 10 minutes.

\section{Results and Discussion}

The ethanol extract of Bryophyllum Pinnatum stem are subjects to antidiabetic activity in albino rats. Where in alloxan was used as the diabetogenic agent. The mean \pm SEM Fasting blood glucose level in normal control rats was on 1st day $77.2 \pm 3.42$ and 21 th day was $81.34 \pm 1.86$. A substantial increase in blood glucose levels was reported in a diabetic control group that was $185 \pm 4.34$. Whereas metformin treated group showed progressive reduction in blood glucose levels at 1 st day $188.3 \pm 4.65$ and last day was $87.5 \pm 4.1$. The extract plus low dose of standard drug (metformin) was reduced the fasting blood glucose level at 1st day $178.4 \pm 1.95$ and last day was $103 \pm 2.72$. and the third group i.e. only high dose of extract was significantly reduced blood glucose level at 1st day $160.3 \pm 3.12$ and the last day was $109 \pm 3.98$.

\section{Table: 3 Data showing fasting blood sugar levels} $(\mathrm{mg} / \mathrm{dl})$ at different time intervals.

\begin{tabular}{|c|c|c|c|}
\hline \multirow{2}{*}{ Groups } & \multirow{2}{*}{ Treatment } & \multicolumn{2}{|c|}{$\begin{array}{c}\text { Fasting blood sugar level } \\
\qquad(\mathrm{mg} / \mathrm{dl})\end{array}$} \\
\hline & & $1^{\text {st }}$ day & $21^{\text {st }}$ day \\
\hline Group I & Vehicle control & $77.2 \pm 3.42$ & $81.34 \pm 1.86$ \\
\hline Group II & Negative control & $179.7 \pm 1.95$ & $185 \pm 4.34$ \\
\hline Group III & $\begin{array}{l}\text { High dose of } \\
\text { Ethanol extract }\end{array}$ & $160.3 \pm 3.12 *$ & 109 \\
\hline Group IV & $\begin{array}{l}\text { Low dose of } \\
\text { ethanol extract }\end{array}$ & $178.4 \pm 1.93^{*}$ & $103.4 \pm 2.72 *$ \\
\hline Group V & Standard & $188.3 \pm 4.65^{*}$ & $87.5 \pm 4.1^{* *}$ \\
\hline
\end{tabular}

Figure 2: Fasting Blood sugar levels (mg/dl) at different time intervals

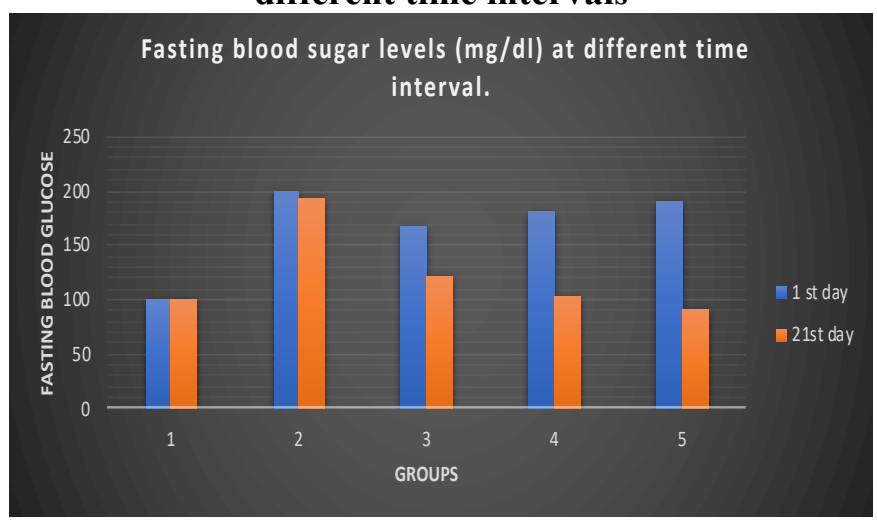

The Table 3 showed a reduction in fasting blood glucose levels in both metformin and extract treated group when comparable with diabetic control. The data were statistically analysed by Student ' $t$ ' test. It indicates a significant difference among the groups at 1 st and $21^{\text {th }}$ days of treatment.

The ethanol extract of Bryophyllum Pinnatum stem is subjected to antidiabetic activity in albino rats. Where in alloxan was used as the diabetogenic agent. The mean \pm SEM Post prandial blood glucose level in normal control rats was on 1 st day $102 \pm 2.86$ and 21 th day was $100 \pm 2.96$. A market reduce in the blood glucose level of the diabetic control group was assessed that was $194 \pm 2.21$. Whereas metformin treated group showed progressive reduction in blood glucose levels at 1 st day $190 \pm 0.91$ and last day was $91 \pm 2.21$. The extract plus low dose of standard drug (metformin) was reduced the fasting blood glucose level at 1 st day 182.6 \pm 4.08 and last day was $104.4 \pm 2.32$ and the third group i.e. only high dose of extract was significantly reduced blood glucose level at 1 st day $168.3 \pm 3.34$ and the last day was $120.8 \pm 3.17$.

The Table- 4 showed a reduction in post prandial blood glucose levels in both metformin and extract treated group when comparable with diabetic control.

The result was analyzed by Student's' test. Student ' $t$ ' test indicates a significant difference among the groups at $1^{\text {st }}$ and $21^{\text {st }}$ days of treatment.

\section{Table: 4 Data showing post prandial blood glucose at} different time interval.

\begin{tabular}{|c|c|c|c|}
\hline Groups & Treatment & \multicolumn{2}{|c|}{$\begin{array}{c}\text { Post Prandial blood sugar } \\
\text { level (mg/dl) }\end{array}$} \\
\hline Group I & Vehicle control & $102 \pm 2.86$ & $100 \pm 2.96$ \\
\hline Group II & $\begin{array}{c}\text { Negative } \\
\text { control }\end{array}$ & $200 \pm 2.32$ & $194 \pm 2.21$ \\
\hline Group III & $\begin{array}{c}\text { High dose of } \\
\text { ethanol extract }\end{array}$ & $168.3 \pm 2.34^{*}$ & $120.8 \pm 3.17^{* *}$ \\
\hline Group IV & $\begin{array}{c}\text { Low dose of } \\
\text { ethanol extract }\end{array}$ & $182.6 \pm 4.08^{*}$ & $104.4 \pm 2.32^{*}$ \\
\hline Group V & Standard & $190 \pm 0.91^{*}$ & $91 \pm 2.21^{* *}$ \\
\hline
\end{tabular}

Where $\mathrm{n}=6 * \mathrm{P}<0.05, * * \mathrm{P}<0.01$ compare to negative control 
Vijay A et.al., Evaluation of Anti-Hyperglycaemic activity of Bryophyllum pinnatum against Type 2 Diabetic rats

Figure-3 Post Prandial blood glucose at different time interval

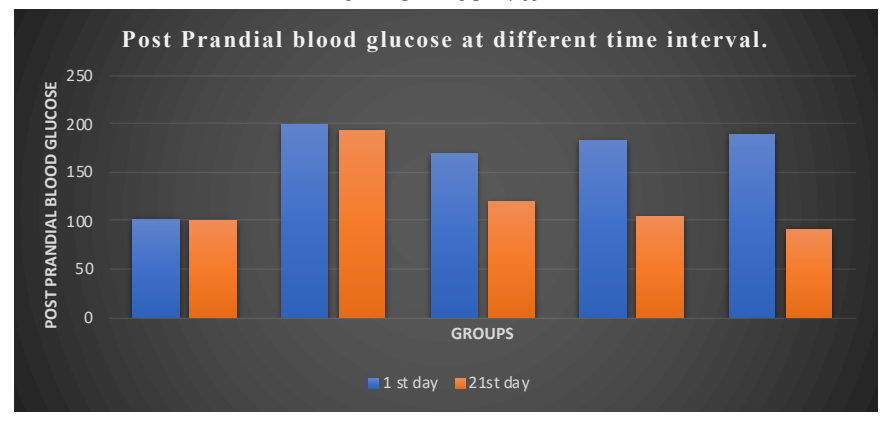

\section{Biochemical parameters studies}

Serum cholesterol

A marked rise in serum cholesterol levels were observed in diabetic control group that was $244.2 \pm$ 6.54. Whereas ethanol extract group have shown a large decrease in cholesterol level at $179.8 \pm 1.98$. And ethanol extract plus metformin low dose group have shown a substantial lowering of blood cholesterol at $158.4 \pm 2.52$. Whereas the fifth group (received metformin) have shown a substantial drop in cholesterol level in the serum at $155.5 \pm 3.72$.

The student ' $t$ ' test indicates a significant difference in serum cholesterol among the metformin and ethanol extract treated groups.

\section{Serum triglycerides}

A marked rise in serum triglycerides levels were observed in diabetic control group that was 166.8 \pm 7.17 . Whereas ethanol extract group have shown a drop in triglyceride levels at $129.8 \pm 3.15$ and ethanol extract plus metformin low dose group have shown a large decrease in triglycerides level at $106 \pm 5.65$. Whereas the fifth groups (received metformin) have shown a signification reduction of serum triglycerides level at $98.5 \pm 1.95$.

The student's' test indicates a significant difference in serum triglycerides among the metformin and ethanol extract treated groups.

\section{Serum HDL}

An improvement in HDL was seen in the diabetic control group that was $38.2 \pm 0.65$. Whereas ethanol extract group have shown a major decrease of HDL in the serum at $47.8 \pm 1.93$. And ethanol extract plus metformin low dose group have shown a drop in the amount of HDL serum at $53.8 \pm 1.15$. Whereas the fifth groups (received metformin) have shown a significant reduction of serum HDL level at $54.5 \pm 1.95$

The student ' $t$ ' test indicates a significant difference in serum HDL among the metformin and ethanol treated groups.

\section{Serum LDL}

We measured a marked increase in serum LDL levels in diabetic group that was $168.8 \pm 3.59$. Whereas ethanol extract group have shown A substantial decrease in serum LDL level at $127.8 \pm 2.90$. And ethanol extract plus metformin low dose group have shown a significant reduction in serum LDL level at $101 \pm 2.90$. And ethanol extract plus metformin low dose group have shown a major reduction in serum LDL level at $101 \pm 3.58$. Whereas the fifth group (received metformin) have shown a significant reduction of serum LDL level at $98.5 \pm 2.16$.

The student ' $\mathrm{t}$ ' test indicates a significant difference in serum LDL among the metformin and ethanol extract treated group.

\section{Serum Creatinine}

A marked rise in serum creatinine levels were observed in diabetic control group that was $1.32 \pm 0.05$. Whereas ethanol extract group have shown a substantial drop in serum creatinine concentration at $0.82 \pm 0.02$. And ethanol extract plus metformin low dose group have shown a substantial decrease in serum creatinine level at $0.732 \pm 0.028$. Whereas the fifth group (received metformin) have shown a significant reduction of serum creatinine level at $0.67 \pm 0.021$.

The student' $t$ ' test indicates a significant different in serum creatinine among the metformin and ethanol extract treaded group.

\section{Serum urea}

A marked rise in serum urea levels were observed in diabetic control group that was $67 \pm 2.43$. Whereas ethanol extract group have shown a significant reduction in serum urea level at $47.2 \pm 3.79$. And ethanol extract plus metformin low dose group have shown a significant reduction in serum urea level at $45.8 \pm 3.22$. Whereas the fifth group (received metformin) have shown a significant reduction of serum urea level at $39.2 \pm 1.70$.

The student's' test indicates a significant different in serum urea among the metformin and ethanol extract treated group. The Biochemical parameters are expressed in Table-5.

\begin{tabular}{|c|c|c|c|c|c|c|c|}
\hline \multirow{2}{*}{ Groups } & Treatment & Seru & Serum & Serum & Sert & Seru & Serum \\
\hline & & Cholesterol & Triglycerides & HDL & LDL & Creatinine & Urea \\
\hline Group I & Vehicle control & $149 \pm 3.77$ & $82.3 \pm 5.4$ & $50.3 \pm 2.95$ & $90.6 \pm 2.90$ & $0.54 \pm 0.03$ & $42 \pm 3.60$ \\
\hline Group II & Negative control & $244.2 \pm 6.54$ & $166.8 \pm 7.17$ & $38.2 \pm 0.65$ & $168 \pm 3.59$ & $1.32 \pm 0.05$ & $67 \pm 2.43$ \\
\hline Group III & High dose of ethanol extract & $179.8 \pm 1.98 *$ & $129.8 \pm 7.17 *$ & $47.8 \pm 1.93^{* *}$ & $127.8 \pm 2.90^{*}$ & $0.82 \pm 0.02 *$ & $47.2 \pm 3.79 * *$ \\
\hline Group IV & Low dose of ethanol extract & $158.4 \pm 2.52 * *$ & $106 \pm 5.65 *$ & $53.8 \pm 1.15^{* *}$ & $101 \pm 3.58^{*}$ & $0.732 \pm 0.028 *$ & $45.8 \pm 3.22 *$ \\
\hline Group V & Standard & $155 \pm 3.72 *$ & $98.5 \pm 1.95^{*}$ & $54.5 \pm 1.95^{* *}$ & $98.5 \pm 2.16^{*}$ & $0.67 \pm 0.021^{*}$ & $39.2 \pm 1.70 *$ \\
\hline
\end{tabular}

Where $\mathrm{n}=6 * \mathrm{P}<0.05,{ }^{*} * \mathrm{P}<0.01$ compare to negative control 
Figure 4 - Bio-chemical parameters after 21 days treatment

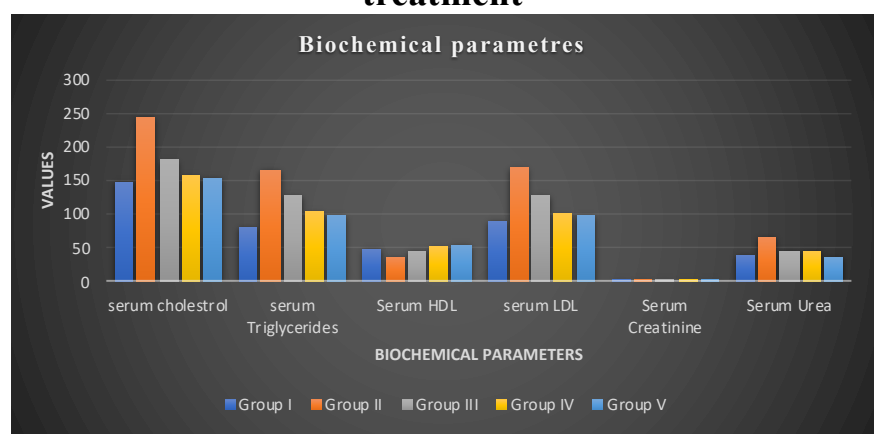

\section{Conclusion}

Ethanol stem extract of Bryophyllum Pinnatum has got significant anti-diabetic activity by its antihyperglycemic action and insulin sensitizing activity greater than control and lesser than reference drug metformin. In addition to regular antidiabetic drugs, Bryophyllum Pinnatum stems can also be considered as an adjuvant agent in the treatment of diabetes management. More studies are required to confirm the anti-diabetic activities of individual phytoconstituents of Bryophyllum Pinnatum in human studies were warranted. Therapeutic potentials of Bryophyllum Pinnatum may helpful in the management of diabetes with minimum complications. It may useful in the prevention of diabetes and other degenerative diseases and to be subjected for further research.

\section{References}

1. Craig ME, Hattersley A, Donaghue KC. Definition, epidemiology and classification of diabetes in children and adolescents. Pediatr Diabetes 2009; $10 ; 3-12$.

2. Thévenod F. Pathophysiology of diabetes mellitus type 2: Roles of obesity, insulin resistance and cell dysfunction. Front Diabetes Basel Karger 2008; 19; 1-18.

3. Jung HA, Islam MD, Kwon YS, Jin SE, Son YK, Park JJ, et al. Extraction and identification of three major aldose reductase inhibitors from Artemisia montana. Food Chem Toxicol 2011; 49; 376-384.

4. Akinpelu DA: Antimicrobial activity of Bryophyllum pinnatum leaves. Fitoterapia. 2000, 71 (2); 193-194.

5. Misra SaD SN: Antifungal activity of leaf extract of some higher plants. Acta Botanica Indica. 1979; 7; 147-150.

6. Pandian $\mathrm{P}$ In vivo Anti-Diabetic Activity of the Ethanolic Crude Extract of Vallaris solanacea Leaves. Ind J.Nat.Sci 2020;10 (59);18791-18797

7. Marudamuthu AS P, Leela V. Effect of pterostilbene on lipids and lipid profiles for diabetes, in Streptozotocin-Nicotinamide induced type 2 diabetes mellitus, J. Applied Biomedicine. 2008; 6; 31-37. 